ZOOLOGIA 27 (5): 703-708, October, 2010

doi: $10.1590 /$ S1984-46702010000500006

\title{
Abiotic correlates of temporal variation of Hypsiboas leptolineatus (Amphibia: Hylidae)
}

\section{Cristiane Hiert ${ }^{1} \&$ Mauricio Osvaldo Moura ${ }^{2,3}$}

\author{
${ }_{1}^{1}$ Museu de Ciências Naturais de Guarapuava, Universidade Estadual do Centro-Oeste. Caixa Postal 3010, \\ 85010-990, Guarapuava, PR, Brazil.E-mail: crishiert@gmail.com \\ 2 Departamento de Zoologia, Universidade Federal do Paraná. Caixa Postal 19020, 81531-980, Curitiba, PR, Brazil. \\ ${ }^{3}$ Corresponding author. E-mail: mauricio.moura@ufpr.br
}

\begin{abstract}
Studies of anuran population dynamics are key to uncovering the mechanisms responsible for temporal fluctuations in abundance and those that shape population structure. Population structure and population fluctuations can result from species specific demographic and behavioral characteristics, reproductive microhabitat availability (which is influenced by local environment and climate), as well as from responses to populations of other, sympatric species. In view of this, our study aimed to ascertain the temporal trends in a population of Hypsiboas leptolineatus, to describe how abundance changes between seasons, and to uncover the effects of environmental variables in shaping seasonal variations in abundance. Although $\mathrm{H}$. leptolineatus occurs throughout the year, abundance showed a clear seasonal pattern linked to an interaction between temperature, relative air humidy, and moon phase.
\end{abstract}

KEY WORDS. Anura population structure; calling pattern; moon-phase; temporal fluctuations.

Temporal trends in populations depict fluctuations in abundance through time in response to several environmental and biotic factors. Particularly in anurans, environmental factors are fundamental in driving temporal trends (DuelLman \& TRUeB 1994), although reproductive traits and biotic interactions such as predator-prey dynamics also play a significant role (Tofт 1980). In this sense, environmental factors exert direct and indirect effects on population trends through physiological constraints imposed on life history traits such as reproductive activity, social interactions, and prey dynamics (Duellman \& Trueb 1994, Marsh 2000, Toft 1980, Lingnau \& Bastos 2007).

Among the environmental variables measured in studies of temporal fluctuations in frog populations, temperature and accumulated rainfall appear to be the critical factors driving population activity (Duellman \& Trueb 1994, Marsh 2000, Oseen \& Wassersug 2002, Boquimpani-Freitas et al. 2007). However, barometric pressure, light intensity, photoperiod, and wind velocity have also had their effects described (Duellman \& TRUEB 1986, Marsh 2000, Oseen \& Wassersug 2002, Boquimpani-Freitas et al. 2007). Though they have been studied less frequently (Oseen \& WASSERSUG 2002).

Despite the large covariation among environmental factors, it is possible that each influences anuran activity differently (ВRооке et al. 2000). This may be particularly true when it comes to certain specific bionomic features such as reproductive mode. The influence of environmental factors on reproduction should be much more evident in explosive breeding species (Boquimpani-Freitas et al. 2007) than in continuous breeders.
In the first case the relationship between the reproductive period and the beginning of the rainy season is clear (MARSH 2000). In the latter, by contrast, such relationship is not so obvious, because the species reproduces throughout the year regardless of the season [or other environmental factors]. In such case, the relationship between abundance and abiotic factors (MARSH 2000, Oseen \& Wassersug 2002, SAenz et al. 2006) may be explained by two hypotheses. The first hypothesis predicts that there is no strict correlation between environmental factors and activity patterns (MARSH 2000). The alternative hypothesis, by contrast, predicts the existence of some environmental cue that signals the appropriate time when the trade-off between vocalization costs and reproduction will be maximized, what would result in a positive correlation between at least one abiotic factor and abundance (Oseen \& Wassersug 2002, Saenz et al. 2006).

Hypsiboas leptolineatus (Braun \& Braun, 1977) belongs to the $H$. polytaenius (Cope, 1870) clade (Farvovich et al. 2005). The species occurs in marshes and riverine systems at high altitude grasslands in the Araucaria plateau of the states of Rio Grande do Sul, Santa Catarina and Paraná (Braun \& Braun 1977, Cruz \& Caramaschi 1998, Kwet \& Di-Bernardo 1999, Hiert \& Moura 2007). Available data for the species include reproductive behavior, call characteristics, and description of the tadpole (КwEт 2001, Вотн et al. 2007), although basic population parameters are still lacking (IUCN 2009).

Basic population information on survivorship, reproductive and dispersion patterns is extremely relevant for anuran conservation efforts. In particular, understanding temporal 
fluctuations in abundance is an important step in planning and evaluating population studies. The goal of this paper was to describe seasonal trends in a population of Hypsiboas leptolineatus by describing how abundance changes between seasons, and investigating the effects of environmental variables in shaping seasonal variations in abundance.

\section{MATERIAL AND METHODS}

The study was carried out in Rio do Salto, Municipality of Turvo $\left(25^{\circ} 01^{\prime} 40,9^{\prime \prime} \mathrm{S}, 51^{\circ} 32^{\prime} 40,4^{\prime \prime} \mathrm{W}, 1.200\right.$ above sea level), state of Paraná, Brazil. The area belongs to an Ombrophilous mixt forest or Araucaria Forest phytophisionomy, mixed with grasslands in a vegetation matrix denominated "Campos de Guarapuava" (MAACK 1981, CASTELLA \& BRITEZ 2004).

The study site comprises an area of $24.000 \mathrm{~m}^{2}$ composed predominantly of grasslands, small bushes, and few trees with a mosaic of temporary and permanent pools linked by streams. During the rainy season, two permanent pools (501 and $3,395 \mathrm{~m}^{2}$, maximum depth $70 \mathrm{~cm}$ ) are connected by six, $50 \mathrm{~cm}$ deep creeks that vary from 20 to $105 \mathrm{~cm}$ in width.

Sampling took place from October 2006 to September 2007, with two sampling periods of three nights each carried out monthly, totaling a six night sampling program each month. The field sampling nights lasted in average eight hours/ night, beginning before sunset (around 17:00 h) and lasting until male calling activity ended or became too infrequent (calls spaced by at least 15 minutes). During each sampling night, the beginning of calling activity was recorded as the time when the first $H$. leptolineatus male began to call.

The abundance of $H$. leptolineatus was determined by two conventional sampling methods, visual encounter and audio surveys (Crump \& Scott Jr 1994, Aurichio \& Salomão 2002, Pierce \& GuTZWiLler 2004). Each sampling night, two persons searched all ponds and riverines within the area for six hours each, yielding an average sampling effort of 560 hours/person.

Each individual found was captured, individually marked in the field (to avoid measuring the same individual in subsequent sampling sessions) using a pelvic ring with colored bead following (Narvaes \& Rodrigues 2005, Giasson \& Haddad 2007), weighted (Pesola ${ }^{\circledR}$, precision of $0.25 \mathrm{~g}$ ), measured (snout-vein length, precision of $0.1 \mathrm{~mm}$ ), and sexed (based on secondary sexual characters, presence of vocal sacs, and throat color). Post metamorphic individuals and juveniles were not marked but were measured as described above. Specimens were released where they had been captured.

Air and water temperature and relative humidity were recorded during each sampling night. Records of sunset times and moon phases were obtained from Instituto Tecnológico SIMEPAR. Figure 1 shows the monthly distribution of climatic variables (accumulated rainfall, minimum and maximum temperature) in the region.

Raw data was modified following ZAR (1984), as follow: relative humidity was arcsine transformed; air temperature,

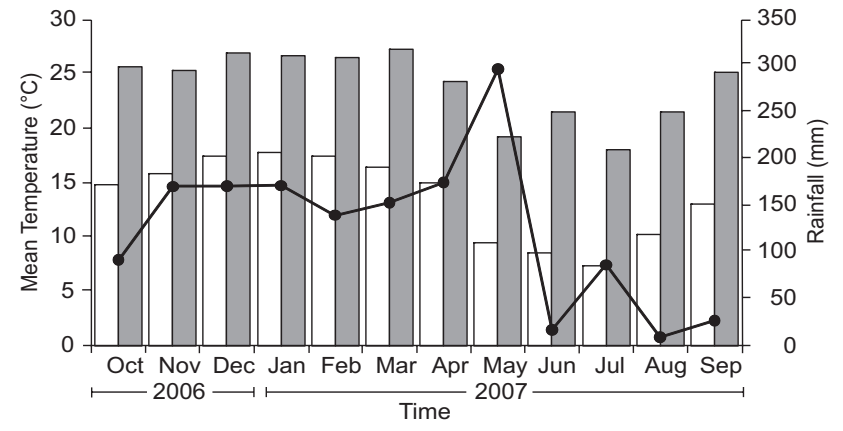

Figure 1 . Monthly average minimum temperature (white bars), maximum temperature (black bars) and accumulated rainfall (line) at the study site from October 2006 to September 2007. Source: Instituto Agronômico do Paraná (IAPAR).

water temperature and precipitation were log transformed, and abundance was square root transformed.

The influence of seasonal patterns (predictor variable) and moon phase (predictor variable) influencing abundance (number of individual sampled/night) on H. leptolineatus (response variable) were tested using two separate one way ANOVAs with season (spring, summer, autumn and winter) or moon phase as fixed effects. The post hoc comparisons between means were done with Tukey post hoc test (ZAR 1984).

To test the effect of environmental variables (minimum, maximum water temperature and relative air humidy) on abundance (response variable), we used a general linear model where all main effects and biological meaningful interactions were used.

The effect of sunset time on the onset of calling activities in H. leptolineatus was evaluated through a simple linear regression. To test for seasonal influences (fixed predictor variable) on the beginning of the calling activity we used a one way ANOVA, where the response variable was the difference between sunset time and the time when males began to call (Zar 1984).

All analyses were performed in JMP (versão 5.0.1.2. The Statistical Discovery Software. Copyright $\left.{ }^{\circ} 1989-2003\right)$ with an alpha set to 0.05 .

\section{RESULTS}

We captured and marked 374 individuals, of which 353 were males and only 21 were females, giving an extremely biased sex ratio. Size ranged from 29.2 to $33.9 \mathrm{~mm}$ (32.7 \pm 0.97 $\mathrm{mm}$; mean $\pm 1 \mathrm{SD})$ for females and from 25.3 to $32.7 \mathrm{~mm}$ (29.33 $\pm 1.34 \mathrm{~mm}$; mean $\pm 1 \mathrm{SD}$ ) for males. The weight ranged from 1 to $1.75 \mathrm{~g}(1.37 \pm 0.15 \mathrm{~g}$; mean $+1 \mathrm{SD})$ for adult females and 0.5 to $1.5 \mathrm{~g}(0.99 \pm 0.21 \mathrm{~g}$; mean $\pm 1 \mathrm{SD})$ for adult males. Juveniles $(\mathrm{n}=33)$ had an SVL ranging from 15.8 to $19.3 \mathrm{~mm}(17.09 \pm$ $0.88 \mathrm{~mm}$; mean $\pm 1 \mathrm{SD}$ ). As no juvenile was individually marked, it is possible that we measured the same individual more than once. 
Monthly variation in the abundance of $H$. leptolineatus (mean $\pm 1 \mathrm{SD}$ ) during the sampling period is shown in figure 2 . Males were found vocalizing throughout the year and females were not recorded in October only. Reproductive females and clutches were recorded in March, June, and November, whereas juveniles (post-metamorphic individuals) were recorded most of the year, excluding April and November.

There was a marked seasonal variation in the abundance of $H$. leptolineatus between seasons $\left(\mathrm{F}_{3,67}=9.20, \mathrm{p}<0.05\right)$, with greatest abundance means found in winter and spring (Fig. 3). The linear generalized model, constructed with all abiotic vari- ables, was highly significant to explain abundance differences among seasons $\left(\mathrm{F}_{21,49}=2.20, \mathrm{p}=0.01\right)$. The main factors alone were not significant to explain the pattern; however, when temperature and relative humidity were combined (interaction term), the effect was significant (Tab. I). Incorporating water temperature in the models did not improve any of the previous results. Also, we found an effect of moon phases on abundance patterns $\left(\mathrm{F}_{3,67}=28.5, \mathrm{p}<0.05\right)$, with the greatest mean abundance found in new moon, whereas all others (full moon, first quarter and last quarter moon phases) showed similar mean abundance values (Fig. 4).

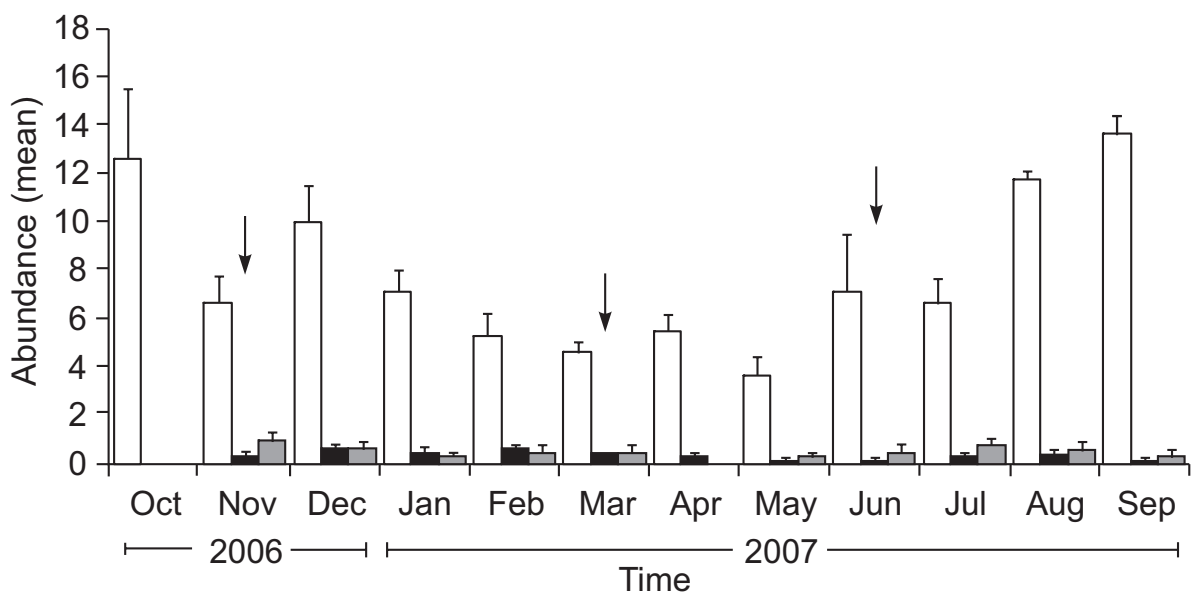

Figure 2. Abundance (mean \pm SD) of males (white bars), females (black bars), juveniles (gray bars) and egg clutches (arrows) of Hypsiboas leptolineatus, recorded from October 2006 to September 2007.
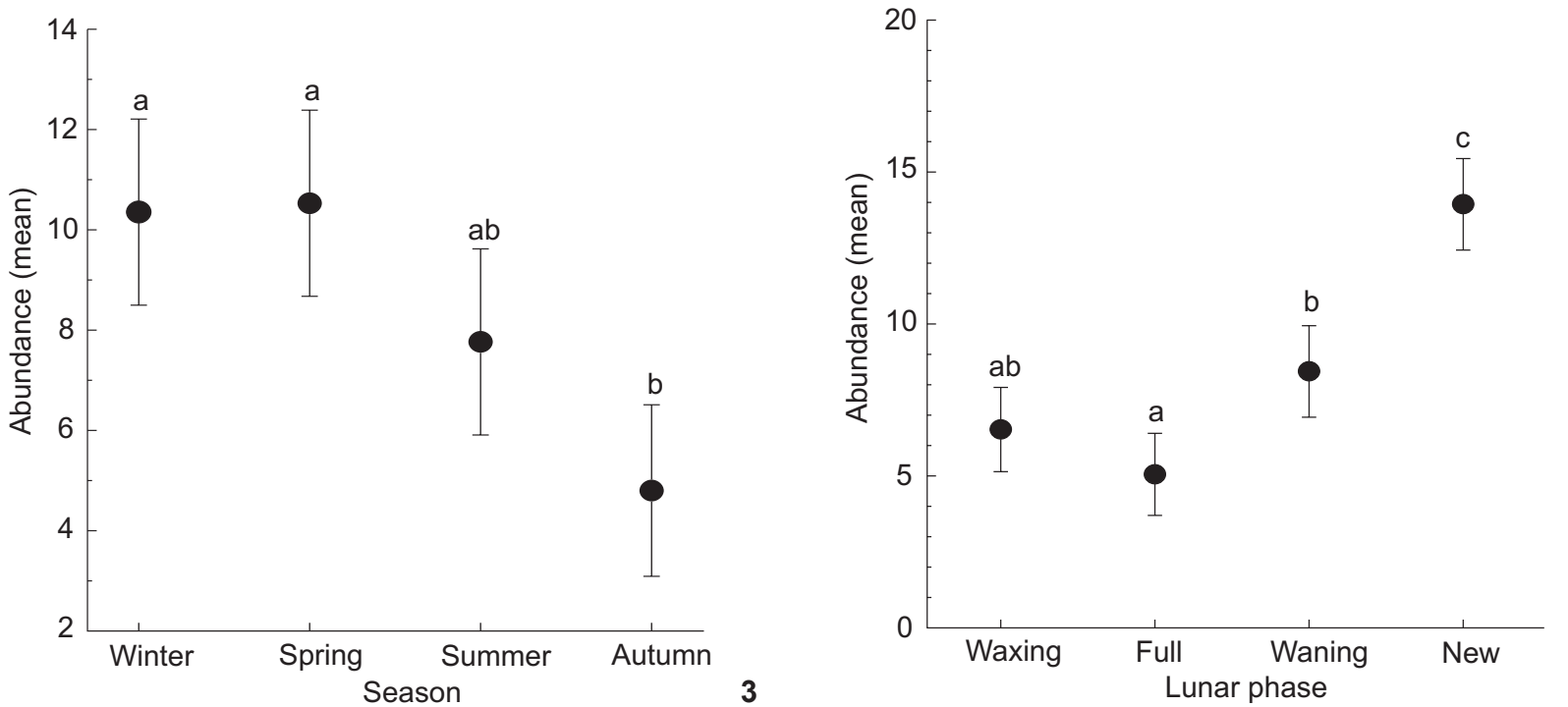

Figures 3-4. Patterns of abundance (mean \pm confidence interval) of Hypsiboas leptolineatus between seasons (3) and between moon phases (4). Different letters $(a, b, c)$ indicate statistical differences, based on Tukey's comparison of means test. 
Table I. Generalized linear models with main and interaction $\left({ }^{*}\right)$ terms tested as explanatory models for temporal fluctuations in abundance of $H$. leptolineatus.

\begin{tabular}{|c|c|c|}
\hline Factor & $\mathrm{F}$ & $p$ \\
\hline Minimum Temperature & 0.24 & 0.63 \\
\hline Maximum Temperature & 0.03 & 0.86 \\
\hline Minimum Humidity & 0.65 & 0.42 \\
\hline Maximum Humidity & 0.57 & 0.45 \\
\hline Water Temperature & 0 & 0.99 \\
\hline$($ Minimum $\mathrm{T}) \star($ Minimum $\mathrm{H})$ & 3.66 & 0.06 \\
\hline$($ Minimum $\mathrm{T}) \star($ Maximum $\mathrm{H})$ & 8.18 & 0.01 \\
\hline$($ Minimum $T) *($ Water $T)$ & 1.20 & 0.28 \\
\hline$(\text { Maximum } \mathrm{T})^{\star}($ Minimum $\mathrm{H})$ & 3.06 & 0.08 \\
\hline$($ Maximum $\mathrm{T}) *($ Maximum $\mathrm{H})$ & 4.3 & 0.04 \\
\hline$($ Maximum $T) *($ Water $T)$ & 0.41 & 0.52 \\
\hline$(\text { Minimum } \mathrm{H})^{\star}($ Water $\mathrm{T})$ & 0.62 & 0.43 \\
\hline$($ Maximum $\mathrm{H}) *($ Water $\mathrm{T})$ & 0.01 & 0.94 \\
\hline$(\text { Minimum } \mathrm{T})^{\star}(\text { Minimum } \mathrm{H})^{\star}($ Water $\mathrm{T})$ & 0.63 & 0.43 \\
\hline$(\text { Minimum } T)^{\star}(\text { Maximum } H)^{*}($ Water $T)$ & 1.36 & 0.25 \\
\hline$(\text { Maximum } T)^{\star}(\text { Minimum } H)^{\star}($ Water $T)$ & 0.1 & 0.76 \\
\hline$($ Maximum $\mathrm{T}) *(\text { Maximum } \mathrm{H})^{\star}($ Water $\mathrm{T})$ & 0.29 & 0.59 \\
\hline
\end{tabular}

The time when males began to call is highly dependent on sunset time (Fig. 5), occurring about half an hour after sunset (Vocalization time $=-0.18 \pm 1.27$ (Sunset time); $\mathrm{r}^{2}=0.89$, $\mathrm{F}_{2,68}=287.46, \mathrm{p}<0.05$ ). The difference (in minutes) between sunset time and time of first calling has a seasonal component $\left(\mathrm{F}_{3,67}=12.02, \mathrm{p}<0.05\right)$ decreasing from summer (one hour after sunset) to winter (half an hour after sunset) (Fig. 6).

\section{DISCUSSION}

Seasonal variation in anuran populations has been usually attributed to environmental filters that either trigger reproduction or constrain it by imposing physiological limitations (Duelmann \& Trueb 1994, Watling \& Donnelly 2002). In general, there is a continuum of breeding strategies from continuous to explosive breeders. Their response and dependence on abiotic factors will in turn shape the temporal fluctuations in their populations. Our results on temporal fluctuation support the idea that $H$ leptolineatus is a continuous breeder. Males call throughout the year, postmetamorphic individuals were found in almost all months, and gravid females and clutches were found in different seasons. Although we are using calling as a surrogate of breeding activity, histological analysis of $H$. leptolineatus has revealed that mature males can be found throughout the year (MAYER \& MOURA, pers.obs.).

It is possible that male activity patterns and postmeta-

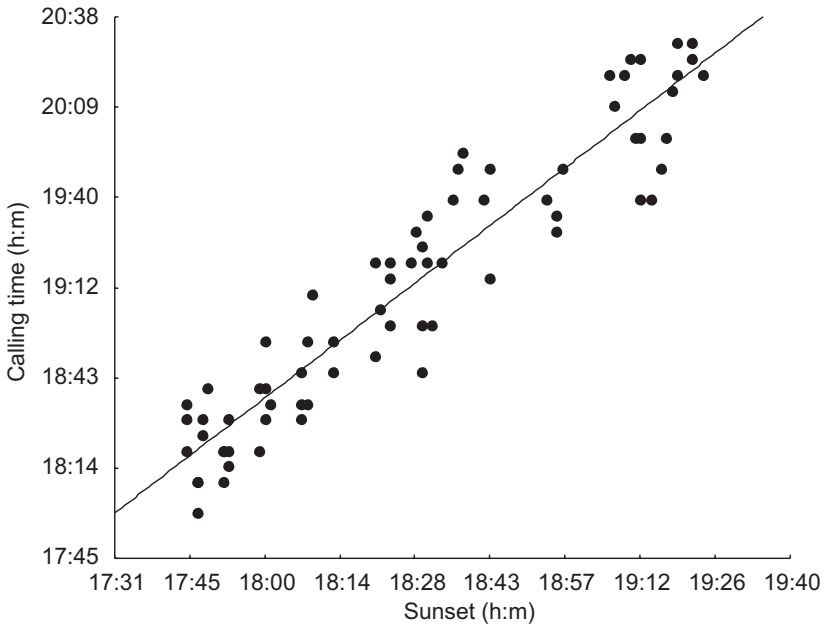

Figure 5. Linear regresion between time of sunset and time of first calling male of Hypsiboas leptolineatus.

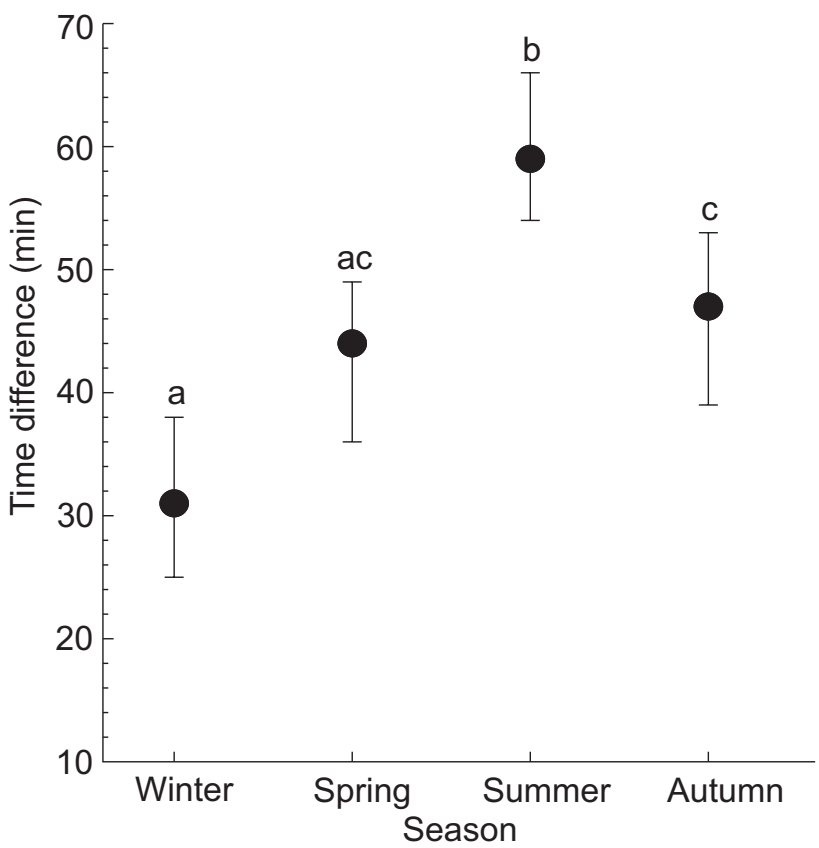

Figure 6. Seasonal time differences (mean \pm confidence interval) between time of sunset and time of first calling male of Hypsiboas leptolineatus. Different letters $(a, b, c)$ indicates statistical differences, based on Tukey's comparison of means test.

morphic temporal distribution are features common to the entire Hypsiboas polytaenius clade (Kwet \& Di-Bernardo 1999, EтеRovick et al. 2002, Вотн et al. 2007). However, data are not available for all species. Furthermore, in its southern range, $H$. lepolineatus reproduces from spring to autumn, and there are no reproduction records for this species in the winter (KWET \& 
Di-BERNARDO 1999). This may be a reflection of geographic variation in life history traits, or of different population and community structures on both sites (Brooke et al. 2000). However, one of the most common life history proxies, body size (Roff 1992), usually represented by SVL in anurans, did not differ between populations $720 \mathrm{Km}$ apart, living in the southern (Braun \& Braun 1977, Kwet \& Di-Bernardo 1999) and northern range limits (this study). The strong sex ratio bias reported here was also reported for another population (BRAUN \& BRAUN 1977).

The response of anurans species to temporal fluctuations in climatic variables could be either to a specific variable (Duellman \& Trueb 1994) or to an interaction between different variables (Marsh 2000, Saenz 2006, Boquimpani-Freitas et al. 2007, BASTAZINI et al. 2007). Furthermore, this response could be scaledependent (BRoокe et al. 2000, Costa et al. 2008). The population of $H$. leptolineatus we studied showed a clear seasonal abundance pattern linked to an interaction between temperature and relative air humidy. Furthermore, the moon phases also have a clear effect on population fluctuations. This pattern is similar to that recorded for $H$. pulchellus. Males of the latter did not call only in summer and were negatively associated with photoperiod and temperature (Вотн et al. 2007), reflecting the rise in abundance nearing cold months.

The onset of male activity in $\mathrm{H}$. leptolineatus has a temporal component dependent on sunset time, reflecting the effect of the photoperiod. In summer and spring males began to calling consistently later in cooler months

in comparison with their summer vocalization activity. This pattern could be produced by mechanisms linked to light intensity (moon phases) since our data indicate that less light intensity (new moon) leads to greater abundance. A similar pattern in modal peak arrivals and first sightings in new moon were found for other amphibians (Grant et al. 2009). In this sense, behavioral mechanisms, such as predator avoidance (Duelmann \& Trueb 1994, Oseen \& Wassersug 2002, Grant et al. 2009) or calling behavior (Almeida-Gomes et al. 2007) as well as physiological constraints associated with an increase in relative air humidity (Oseen \& Wassersug 2002) could all lead to this pattern. Our data are not sufficient to test candidate mechanisms. However, the fact that photoperiod is an important environmental factor for several animal groups (Bradshaw \& Holzapfel 2007), being an effective and general environmental cue for anurans at the community (Both et al. 2007) and population levels (Hatano et al. 2002, Almeida-Gomes et al. 2007) in both diurnal (Hatano et al. 2002, Almeida-Gomes et al. 2007) and nocturnal species (Both et al. 2007) suggest that it is a possible explanation for the pattern of male activity period. However, this hypothesis needs further investigation.

The pattern of temporal variation in the population of $H$. leptolineatus we have studied is linked to an interaction between temperature and relative air humidity favoring the hypotheses that calling behavior is maximized (OSEEN \& WASSERSUG 2002, SAENZ et al. 2006) using these cues.

\section{ACKNOWLEDGMENTS}

This study was carried out within the Programa de PósGraduação em Ecologia e Conservação of Universidade Federal do Paraná. Emygdio L. de A. Monteiro-Filho and Luis F. Toledo made helpful comments on previous version of the manuscript. This research was partially supported by grants from the Conselho de Desenvolvimento Científico e Tecnológico (CNPq process 312357/2006) to Mauricio O. Moura.

\section{LITERATURE CITED}

Almeida-Gomes, M.; M. Van Sluys \& C.F.D. Rocha. 2007. Calling activity of Crossodactylus gaudichaudii (Anura: Hylodidae) in an Atlantic Rainforest area at Ilha Grande, Rio de Janeiro, Brasil. Belgian Journal of Zoology 137: 203-207.

Aurichio, P. \& M.G. SAlomão. 2002. Técnicas de coleta e preparação de vertebrados para fins científicos e didáticos. São Paulo, Instituto Pau Brasil de História Natural, 350p.

Bastazini, C.V.; J.F.V. Munduruca; P.L.B. Rocha \& M.F. Napoli. 2007. Which environmental variables better explain changes in anuran community composition? A case study in the restinga of Mata de São João, Bahia, Brazil. Herpetologica 63 (4): 459-471.

Boquimpani-Freitas, L.; R.V. Marra; M. Van Sluys \& C.F.D. Rocha. 2007. Temporal niche of acoustic activity in anurans: interspecific and seasonal variation in a neotropical assemblage from south-eastern Brazil. Amphibia-Reptilia 28: 269-276.

Both, C.; A. Kwet \& M. Solé. 2007. The tadpole of Hypsiboas leptolineatus (Braun and Braun, 1977), a species in the Hypsiboas polytaenius clade (Anura: Hylidae). Brazilian Journal of Biology 67 (2): 309-312.

BradshaW, W.E. \& C.M. Holzapfel. 2007. Evolution of Animal Photoperiodism. Annual Review of Ecology and Evolution 38: $1-25$.

Braun, P.C. \& C.A.S. Braun. 1977. Nova espécie de Hyla do estado do Rio Grande do Sul, Brasil (Anura, Hylidae). Revista Brasileira de Biologia 37 (4): 853-857.

BRooke, P.N.; R.A. Alford \& L. SCHWARZKopf. 2000. Environmental and social factors influence chorusing behaviour in a tropical frog: examining various temporal and spatial scales. Behavioral Ecology and Sociobiology 49 (1): 79-87.

Castella, P.R. \& R.M. DE Britez. 2004. A Floresta com Araucária no Paraná - Conservação e diagnóstico dos Remanescentes Florestais. Brasília, Ministério do Meio Ambiente, 236p.

Costa, G.C.; C. Wolfe; D.B. Shepard; J.P. Caldwell \& L.J. VitT. 2008. Detecting the influence of climatic variables on species distributions: a test using GIS niche-based models along a steep longitudinal environmental gradient. Journal of Biogeography 35: 637-646.

Crump, M.L. \& N.J. Scott JR. 1994. Standart techniques for inventory and monitoring - Visual encounters surveys, 
p. 84-91. In: W.R. Heyer; M.A. Donnelly; R.W. McDiarmid; L.C. НAYEK \& M.S. Foster (Eds). Measuring and Monitoring Biological Diversity - standard methods for amphibians. Washington, D.C., Smithsonian Insitution Press, XIX+364p.

Cruz, C.A.G. \& U. Caramaschi. 1998. Definição, composição e distribuição geográfica do grupo de Hyla polytaenia COPE, 1870 (Amphibia, Anura, Hylidae). Boletim do Museu Nacional 392: 1-19.

Duellman, W.E. \& L. Trueb. 1994. Biology of Amphibians. New York, McGraw-Hill, 670p.

Eterovick, P.C.; I.S. Barros \& I. SAZIMA. 2002. Tadpoles of two species in the Hyla polytaenia species group and comparison with other tadpoles of Hyla polytaenia and Hyla pulchella groups (Anura, Hylidae). Journal of Herpetology 36 (3): 512-515.

Faivovich, J.; C.F.B. Haddad; P.C.A. Garcia; D. Frost; J.A. Campbell \& W.C. Wheeler. 2005. Systematic review of the frog family Hylidae, with especial reference to Hylinae: phylogenetic analysis and taxonomic revision. Bulletin of the American. Museum of Natural History 294: 1-240.

Giasson, L.O.M. \& C.F.B. Haddad. 2007. Mate choice and reproductive biology of Hypsiboas albomarginatus (Anura: Hylidae) in the Atlantic forest, southeastern Brazil. South American Journal of Herpetology 2 (3): 157-164.

Grant, R.A.; E.A. Chadwick \& T. Halliday. 2009. The lunar cycle: a cue for amphibian reproductive phenology? Animal Behaviour 78: 349-357.

Hatano, F.H.; C.FD. Rocha \& M. Van Sluys. 2002. Environmental factors affecting calling activity of a tropical diurnal frog (Hylodes phyllodes: Leptodactylidae). Journal of Herpetology 36: 314-318.

Hiert, C. \& M.O. Moura. 2007. Anfíbios do Parque Municipal das Araucárias, Guarapuava - Paraná. Guarapuava, Editora UNICENTRO, 41p.

IUCN 2009. IUCN Red List of Threatened Species. Version 2009.1. Available online at: http://www.iucnredlist.org.html. [Accessed: 1/X/2009].

KwET, A. 2001. Frösche im brasilianischen Araukarienwald.
Anurengemeinschaft des Araukarienwaldes von Rio Grande do Sul: Diversität, Reproduktion und Ressourcenaufteilung. Münster, Natur und Tier-Verlag, 192p.

Kwet, A. \& M. Di-Bernardo. 1999. Anfibios - Amphibien Amphibians. Porto Alegre, EDIPUCRS, 108p.

LingnaU, R. \& R.P. Bastos. 2007. Vocalizations of the Brazilian torrent frog Hylodes heyeri (Anura: Hylodidae): Repertoire and influence of air temperature on advertisement call variation. Journal of Natural History 41 (17-20): 1227-1235.

MAACK, R. 1981. Geografia Física do Estado do Paraná. Rio de Janeiro, José Olympio Editora, 450p.

MARSH, D.M. 2000. Variable responses to rainfall by breeding Tungara frogs. Copeia (4): 1104-1108.

Narvaes, P. \& M.T. Rodrigues. 2005. Visual communication, reproductive behavior, and home range of Hylodes dactylocinus (Anura, Leptodactylidae). Phyllomedusa 4 (2): 147-158.

Oseen, K.L. \& R.J. Wassersug. 2002. Environmental factors influencing calling in sympatric anurans. Oecologia 133: 616-625.

Pierce, B.A. \& K.J. Gutzwiller. 2004. Auditory sampling of frogs: detection efficiency in relation to survey duration. Journal of Herpetology 38 (4): 495-500.

RoFf, D.A. 1992. The evolution of life histories: theory and analysis. New York, Chapman and Hall, 465p.

Saenz D.; L. Fitzgerald; K. Baum \& R. Conner. 2006. Abiotic Correlates of Anuran Calling Phenology: The Importance of Rain, Temperature, and Season. Herpetological Monographs 20: 64-82.

ToFт, C.A. 1980. Seasonal variation in populations of Panamanian litter frogs and their prey: a comparison of wetter and dryer sites. Oecologia 47: 34-38.

Watling, J.I. \& M.A. Donnelly. 2002. Seasonal patterns of reproduction and abundance of leaf litter frogs in a central America rainforest. Journal of Zoology 258: 269-276.

ZAR, J.H. 1984. Biostatistical Analysis. New Jersey, Prentice Hall International, $2^{\text {nd }}$ ed., $718 \mathrm{p}$.

Submitted: 13.X.2009; Accepted: 21.V.2010.

Editorial responsibility: Ana Lúcia da C. Prudente

ZOOLOGIA 27 (5): 703-708, October, 2010 